\title{
松川圭男**
}

Facts and Problems of Raremetal Resources

Yoshio MATSUKAWA

1.レアメタルの重要性

2. レアメタル問題の背景

3. レアメタル資源供給上の問題点

4. レアメタル資源安定供給確保策の現状

5. 参考・引用文献

\section{1. レアメタルの重要性}

戦後の我が国経済の高度成長の重要な要因の一つに, 海外資源に対する自由なアクセスがあげられる。しかし 1960年代に入ってから, 発展途上国における資源ナショ ナリズムの動きが活発化し，資源を自国の経済発展の原 動力とするために, 資源開発, 資源加工, 資源貿易に対 する介入を強めてきた。

一方，資源小国でありかつ資源大消費国である我が国 にとって, 資源の安定供給確保問題は, 今後の我が国の 経済運営の鍵を握る最む重要な問題の一つであることは 論をまたない。今後の我が国の進むべき道は，技術立国 を目ざした産業の高度化であり，乙の中心となるものは 電子産業, 航空・宇宙産業, 原子力を中心としたエネル ギー産業等のいわゆる技術先端産業であると云われて久 しいが，乙れら産業の発展のための必要不可欠な原材料 として登場するのが, レアメタルと呼ばれる一連の金属 である。

てれまでの新産業や新技術の開発, 発展には必ずと云 っていいほど新しい素材の誕生が前提となってきた。レ アメタルと呼ばれる金属材料は比重, 融点, 硬度, 熱伝 導, 電気抵抗, 磁性, 而熱性, 而摩耗性, 而蝕性, 放射性, 半 導性等で固有の特徵をあち，また純粋な金属としてばか りではなく, 酸化物や他の化合物の形でもその特性が利 用され，他の金属との合金になると，本来の性質を変え たり，より高性能の金属を作り出すととができたりする。

* 昭和62年11月 11 日本会第79回例会において発表

** 金属鉱業事業団海外部次長 昭和 62 年 9 月 30 日受理
現在は，21世紀での開花に向けてェネルギー，情報， 航空・宇宙, 高速鉄道輸送, 医療等のハイテク技術分野 で，革新的な技術開発が活発に進められている。例えば エネルギー分野では高効率ガスタービン, 太陽電池, 核 融合の開発が, 情報分野では情報処理の高速化, 大容量 化に向けての技術開発が，また航空・宇宙分野では高速 度軽量機体, 高効率エンジンの開発が, 高速鉄道輸送分 野ではリニアモーターカーの開発が，さらに医療分野で は人工臓器の開発がそれぞれ積極的に進められている。 こうした各種の技術開発において，その成否の鍵を握る のが新素材の開発である。

新素材の開発にあたって, 現在では従来の試行錯誤的 な手法に代って，材料の組成や構造のミクロレベルにお ける諸物性発現のメカニズム解明に基づいた材料設計や， 設計された材料の具現化を目的とした構造制御技術によ り新素材を創り出そうとする開発手法が，すでに現実の あのとなってきている。今後新素材の開発競争が激化す る方向にあるといえる。

\section{2. レアメタル問題の背景}

このように，我が国産業はハイテク社会化に向けて新 素材の開発を積極的に進めているが，てれに伴いレアメ タル資源の消費も今後急速に伸びるものと予想されてい る。

通商産業大臣の諮問機関である「鉱業審議会レアメタ ル総合対策特別小委員会」では，1987年 8 月に31鉱種の レアメタルについて，「新素材の現状と見通し」(1984年 3 月一産業構造研究会), 「基礎新素材研究会中間報告」 (1984年 7 月一基礎新素材研究会)，「Mineral Facts and Problems」(1985年版一U.S. Bureau of Mines) 等 を参考にしつつ，2000年における市場規模を1985年と対 比して，第 1 表のとおり予測している。

なお上記小委員会で検討の対象とした 31 鉱種のレアメ タルは次のとおりである。 
第 1 表 2000年におけるレアメタルの市場規模予測

\begin{tabular}{|c|c|c|c|}
\hline & $\begin{array}{l}1985 \text { 年 } \sigma \\
\text { 市場規模 } \mathrm{A}\end{array}$ & $\begin{array}{l}2000 \text { 年 } \text { の } \\
\text { 市場規模 B }\end{array}$ & $\mathrm{B} / \mathrm{A}$ \\
\hline 鉣 種 & \begin{tabular}{|c} 
(百億円) \\
32.0
\end{tabular} & $\begin{array}{c}\text { (百億円) } \\
72.0\end{array}$ & 2.3 \\
\hline 新素材向け & 2.8 & 17.9 & 6.4 \\
\hline 既存素材向け & 29.2 & 54.1 & 1.9 \\
\hline 7 鉱種以外 & 34.7 & 97.9 & 2.8 \\
\hline 新素材向け & 4.0 & 36.0 & 9.0 \\
\hline 既存素材向け & 30.7 & 61.9 & 2.0 \\
\hline 計 & 66.7 & 169.9 & 2.5 \\
\hline 新素材向け & 6.8 & 53.7 & 7.9 \\
\hline 既存素材向け & 59.9 & 116.2 & 1.9 \\
\hline
\end{tabular}

1）現在備蓄の対象となっている鉱種（7 鉱種）

ニッケル, クロム, タングステン，コバルト，モリブ デン, マンガン, バナジウム

2）備蓄対象外のむの（24鉱種）

ニオブ，タンタル，ストロンチウム，アンチモン，白 金, パラジウム，ゲルマニウム，チタン，リチウム， ベリリウム, ガリウム, ボロン, セレン, テルル，ル ビジウム，ジルコニウム，ハフニウム，インジウム， セシウム, バリウム, レニウム, タリウム, ビスマス, レアアース（スカンジウム，イットリウムと原子番号 57-71のランタノイドと呼ばれる元素の総称)。

(1)現在のレアメタルの市場規模は約 6,700 億円である が, これが2000年においては約 1 兆7,000億円となり約 2.5倍に市場規模が拡大する。

(2)このうち，いわゆる新素材向け原材料として使用さ れるレアメタルの市場規模は，現在約 700 億円である が，2000年には5, 400億円となり約 8 倍に拡大する。

(3)新素材向け原材料として使用されるレアメタルの市 場を現在備蓄対象となっている 7 鉱種と 7 鉱種以外に 分けてその伸びをみると, 前者が約 6 倍, 後者が約 9 倍となっており，ガリウム，インジウム，レアアース 等を含む後者の伸びが相対的に大きい。

(4)レアアース等の超電導関連レアメタルの市場は現在 約560億円であるが，乙れが2000年においては約 2,570 億円となり，約 5 倍に市場規模が挔大する。なおてれ には超電導の実用化に伴う需要増は考慮しておらず, 実用化の際には，さらに大きく拡大するむのと予測さ れる。

我が国は現在む世界的にみてレアメタルの大消費国で あり，世界消費の15～20\%を占めている。すでに述べた とおり，今後のハイテク社会化に伴ない消費はますます 拡大する方向にあるといえる。とてろが困ったととには 我が国はレアメタル資源の国内生産はほとんどなく，資 源供給をほぼ全面的に海外に依存せざるをえないのが現

Vol. 34, No. 4 ('87-冬)
状である。

とのような状況にあって，レアメタル資源をどう安定 的に供給するかが, 今後の我が国における産業の発展, 経済の発展, 国民生活の安定之向上のための重要なテー マの一つであり，また我が国の安全保障上の問題でああ る。

\section{3. レアメタル資源供給上の問題点}

レアメタルは, 食糧, 木材等の資源とは異なり再生不 可能な資源であり，次第に地下深部化，奥地化等採掘条 件が悪化する方向にある。また探鉱から生産に至るまで に長期間を要し, さらに現地における道路, 港湾, 町づ くり等のインフラストラクチュアの整備を伴うことが多 く，したがって開発までに長期にわたって巨額の投資を 必要とし, かつ一般の産業とは違って立地の選択が不可 能であるという地下資源開発特有の問題に加えて, 大き なリスクを伴う。

また局地紛争，鉱山ストライキ，災害の発生等の供給 側の問題, 経済変動による需給, 価格の変動, 戦略物資 としての仮需要，国際商品市場における投機等の消費側 の問題, 政治的要因による供給の途絶又は制限等レアメ タルの流通にはさまざまな不安定要因が多い。

これに加えて，レアメタル資源の埋蔵と生産の偏在は 最屯重要な問題である。特に最近問題となっている南部 アフリカ, 共産国, 政情不安定な発展途上国への偏在度 が極めて高く, これがレアメタル資源の安定供給確保上, また安全保障上の重要な問題点とされている。

このようにレアメタル資源の埋蔵と生産は, 特定国ま たは特定地域に偏在しているが, 主要な26のレアメタル 資源の埋蔵と生産の分布を上位 5 力国への偏在度, 南部 アフリカ, 共産圈への偏在度と云う観点でみると第 2 表 および第 3 表のとおりである。

1）埋蔵分布

(1)26鉱種のうちインジウムを除いて，ほとんど全てと あ云える23鉱種が上位 5 力国に $50 \%$ 以上の高率で埋蔵 が集中している。

(2)南アフリカは 8 鉱種について上位 5 力国に位置づけ られ，特にクロム，バナジウム，金，白金族について は第 1 位, マンガン, ジルコニウムは第 2 位の埋蔵国 である。

(3)ソ連は18鉱種について上位 5 力国に位置づけられ, 銀, マンガンは第 1 位, バナジウム, 二オブ, 金, 白 金族については第 2 位の埋蔵国である。また共産圏に 偏在しているむのとしては, アンチモン, タングステ ン,バナジウムがあげられる。

(4)西側先進国のうち上位 5 力国に位置づけられるのは, 米国, カナダ, オーストラリアがほとんどである。 


\begin{tabular}{|c|c|c|c|c|}
\hline 鉱 種 名 & 埋 蔵 上位 5 力 国 名 & $\begin{array}{l}\text { 上位 } 5 \text { 力国 } \\
\text { シェア }\end{array}$ & $\mid \begin{array}{l}\text { 南部アフリリ } \\
\text { カシェア }\end{array}$ & 共産圏シェ \\
\hline アンチモン & 中国，ボリビア，南ア，ソ連，メキシコ & 76.9 & 7.3 & 59.4 \\
\hline ベリリウム & ブラジル, インド, ソ連, 米国, アルゼンチン & 83.1 & 14.1 & 16. 0 \\
\hline ビスマス & 日本（?), オーストラリア，ボリビア，米国 & 66.3 & - & 6.3 \\
\hline ク ム & 南ア，ジンバブェ，フィンランド，ソ連，インド & 98.7 & 97.4 & 0.6 \\
\hline コバルト & ザイール, ザンビア，ソ連，キューバ，フィリピン & 88.7 & 66.2 & 17.0 \\
\hline$=オ フ ゙$ & ブラジル, ソ連，カナダ，ナイジェリア，ザイール & 100.0 & 7.8 & 16.7 \\
\hline ガリ ウ ム & アフリカ, オセアニア, ヨーロッパ, 北アメリカ, 南アメリカ & 97.4 & 40.5 & - \\
\hline ゲルマニウム & アフリカ, ヨーロッパ, 北アメリカ & 100.0 & 54.5 & - \\
\hline 金 & 南ア, ソ連, 米国, オーストラリア, フィリピン & 85.0 & 52.4 & 24.0 \\
\hline インジウム & カナダ，米国，ソ連，ペルー, オーストラリア & 40.0 & - & 10.0 \\
\hline リチウム & チリ，米国，カナダ，ザイール，ソ連 & 98.3 & 10.8 & 8.5 \\
\hline マンガン & ソ連, 南ア, オーストラリア, ガボン, ブラジル & 95.2 & 58.4 & 26.9 \\
\hline 水 銀 & スペイン, ソ連，ユーゴ，中国，米国，イタリア & 81.3 & - & 33.4 \\
\hline モリブデン & 米国，チリ，ソ連，カナダ，ペルー，中国 & 49.8 & - & 7.2 \\
\hline ニッケル & $\begin{array}{l}\text { ニューカレドニア, カナダ, インドネシア, フィリピン, オ } \\
\text { ーストラリア }\end{array}$ & 71.3 & - & 19.2 \\
\hline 白金 族 & 南ア，ソ連，カナダ，米国，ジンバブェ & 100.0 & 82.2 & 16. 9 \\
\hline レアアース & 米国, インド, ソ連，オーストラリア，ブラジル & 93.8 & 5.2 & 6.5 \\
\hline セ レ ン & チリ，カナダ，米国，ペルー，ザンビア & 62.5 & 10.2 & - \\
\hline 銀 & ソ連，カナダ，米国，メキシコ，オーストラリア & 83.6 & 1.8 & 19.7 \\
\hline タンタル & ザイール, ナイジェリア, タイ, マレーシア, ブラジル & 85.4 & 56.9 & 6.9 \\
\hline テ ル ル & チリ, 米国, カナダ, ペルー, ザンビア & 59.2 & 12.7 & - \\
\hline ス ズ & インドネシア, 中国, マレーシア, タイ, ソ連 & 64.5 & 2.0 & 25.0 \\
\hline チ タ ン & ブラジル, インド, カナダ, ノルウェー, 南ア & 80.1 & 12.0 & 1.9 \\
\hline タングステン & 中国，カナダ，ソ連，北朝鮮，オーストラリア & 79.7 & 0.2 & 65.1 \\
\hline バナジウム & 南ア, ソ連, オーストラリア, チリ, フィンランド & 98.2 & 49.4 & 46.0 \\
\hline ジルコニウム & オーストラリア，南ア，米国，インド，ソ連 & 90.3 & 22.0 & 10.8 \\
\hline
\end{tabular}

(5)我が国は見るべきレアメタル資源は全くない。

このように, レアメタル資源埋蔵の偏在性は極めて高 く, エネルギー資源の中で最も偏在性の高い石油の中東 への偏在率 $58 \%$ と比較しても, 更に高い偏在率を示すレ アメタルが多いととを十分認識しておく必要がある。

2）生産分布

(1)全ての鉱種について，生産が上位 5 力国に $50 \%$ 以上 の高率で集中している。

(2)南アフリカは， 7 鉱種について上位 5 力国に位置づ けられ, クロム, バナジゥム, 金については世界最大 の生産国であり，アンチモン，マンガン，白金族につ いても第 2 位の生産国である。

(3) 連はコバルト, ガリウムを除くほとんど全ての鉱 種について上位 5 力国に位置づけられ，水銀，ニッケ ル, マンガン, ベリリウム, 白金族については世界最 大の生産国であり，クロム，タングステン，バナジウ ム, リチウム, タンタル, 金, 銀についてあ第 2 位の 生産国である。
(4)西側先進国では，埋蔵と同様，上位 5 力国に位置づ けられるのは米国，カナダ，オーストラリアがほとん どである。

(5)我が国が上位 5 力国に位置づけられるのはビスマス, インジウムの 2 鈗種であるが, 乙れは銅, 鈆, 亜鉛等 のベースメタルの輪入鉱石からの副産物である。

これらのレアメタル資源以外であ, 南アフリカはエ ネルギー資源であるウラン, 製鉄副原料のホタル石, 耐熱材の石綿等の重要な埋蔵国であり生産国であある し，石油とボーキサイト以外は何でああると云われる ほどの資源大国であり，レアメタルの宝庫であある。

3）消費分布

これらレアメタルの消費については，データが少なく 正確な把握は困難であるが，その特徴をあげれば次のと おりである。

(1)消費の分布は埋蔵および生産とは全く異った傾向を 示しており, OECD (経済協力開発機構) 諸国および ソ連に集中している。 
第 3 表主要レアメタルの生産 状 況

(単位 \%)

\begin{tabular}{|c|c|c|c|c|}
\hline 鉱 種 名 & 生 産 上 位 5 力 国 名 & $\begin{array}{l}\text { 上位 } 5 \text { 力国 } \\
\text { シェア }\end{array}$ & $\begin{array}{l}\text { 南部アフリリ } \\
\text { カシェア }\end{array}$ & 共産圈シェ \\
\hline アンチモン & ボリビア，南ア，中国，ソ連，カナダ & 70.9 & 18. 2 & 31.8 \\
\hline ベリリウム & ソ連, 中国, ブラジル, アルゼンチン, ジンバブェ & 99.2 & 1.6 & 65.0 \\
\hline ビスマス & オーストラリア, メキシコ, 日本 (?), ペルー, カナダ & 89.5 & 12.4 & 12.4 \\
\hline ク口 ム & 南ア, ソ連, アルバニア, トルコ, ジンバブエ & 79.6 & 43.8 & 36.3 \\
\hline コバルト & $\begin{array}{l}\text { ザイール, ニューカレドニア，オーストラリア，ザンビア， } \\
\text { モロッコ }\end{array}$ & 77.9 & 60.7 & 11.2 \\
\hline$=$ オ ブ & ブラジル, カナダ, ソ連, ナイジェリア, タイ & 98.0 & 0.1 & 6.6 \\
\hline ガリ ウ ム & 米国, 西ドイッ, フランス, オーストラリア，ハンガリー & 91.0 & - & 4.9 \\
\hline ゲルマニウム & ザイール，米国，イタリア，ソ連，ナミビア & 76.2 & 36.9 & 9.9 \\
\hline 金 & 南ア, ソ連, カナダ, パプアニューギニア, フィリピン & 89.8 & 60.3 & 20.5 \\
\hline インジウム & カナダ, ソ連, ペルー, 米国, メキシコ, 日本（?） & 52.5 & - & 12.5 \\
\hline リチウ ム & 米国，ソ連，中国，ナミビア，ジンバブェ & 99.7 & 11.7 & 27.2 \\
\hline マン ガン & ソ連, 南ア, ガンボン, ブラジル, オーストラリア & 82.3 & 29.6 & 37.0 \\
\hline 水 銀 & ソ連，スペイン，アルジェリア，米国，中国 & 92.4 & - & 47.2 \\
\hline モリブデン & 米国，カナダ，チリ，ソ連，中国 & 97.9 & - & $12 \cdot 0$ \\
\hline ニッケル & ソ連, カナダ, オーストラリア, ニューカレドニア, キューバ & 70.1 & 8.2 & 27.9 \\
\hline 白 金 族 & ソ連，南ア，カナダ，コロンビア，米国 & 99.2 & 47.5 & 47.5 \\
\hline レアアース & 米国，オーストラリア，ソ連，インド，ブラジル & 95.5 & 0.5 & 8.0 \\
\hline セレン & カナダ, 米国, チリ，ソ連，ザンビア & 66.0 & 15.5 & 14.5 \\
\hline 銀 & メキシコ, ソ連, カナダ, ペルー, オーストラリア & 57.8 & 4.0 & 13.3 \\
\hline タンタ & タイ, ソ連，カナダ，マレーシア，ブラジル & 78.6 & 5.1 & 15. 6 \\
\hline テ ル & 米国, チリ, ソ連, アフリカ, カナダ & 70.9 & 20.0 & 10.9 \\
\hline ズ & マレーシア, ソ連, タイ, ボリビア, インドネシア & 71.2 & 3.8 & 13.9 \\
\hline タン & オーストラリア, カナダ, ノルウェー, 米国, ソ連 & 85.9 & 3.1 & 7.3 \\
\hline タングステン & 中国，ソ連，タイ，米国，ボリビア & 60.8 & 1.9 & 45.6 \\
\hline バナジウム & 南ア，ソ連，米国，フィンランド，中国 & 95.0 & 36.7 & 36.1 \\
\hline ジルコニウム & オーストラリア, 米国, ソ連, 南ア, インド & 98.1 & 8.3 & 10.2 \\
\hline
\end{tabular}

(2)したがって，埋蔵および生産では上位にほとんど位 置づけられなかった日本，西ドイッ，英国，フランス が米国とソ連と並んで上位消費国に入ってくる。

(3)我が国は米国，ソ連と並んでほとんどの鉣種につい て第 3 位以内の大消費国となっており，我が国の世界 消費に占める比率はほぼ15２0\%となっている。

このような OECD 諸国の大きな消費と，乙れに比べ て相対的に小さなレアメタル資源の埋蔵および生産との ギャップは非常に大きく，OECD 諸国は鉱石，中間製 品，地金等の原材料を海外からの輸入に頼らざるをえな い状況にある。ここで, 世界のレアメタル消費地を日本, 米国，ヨーロッパ，ソ連の 4 つの地域に分けて，それぞ れの海外依存度を比較すれば第 4 表のとおりである。

資源の少ない日本之ヨーロッパの海外依存度が高いの は当然であるが，資源国である米国についても，その消 費量が大きいととああって一部の資源を除いて海外依存 度はかなり高い。我が国ではカドミウム，セレンが海外 依存度ゼロとなっているが，乙れらはベースメタルの輸
入鉱石からの副産物として生産されており，原料そのむ のはやはり海外に依存している。

第 4 表 主要各国のレアメタル海外依存度（単位\%）

\begin{tabular}{|c|c|c|c|c|c|}
\hline 鉣 & 米 国 & 日 本 & $\mathrm{EEC}$ & ソ & 連 \\
\hline オ & 100 & 100 & 100 & & 0 \\
\hline ストロンチウム & 100 & 100 & 63 & & 0 \\
\hline マン ガ ン & 100 & 97 & 99 & & 0 \\
\hline コ バ ル & 95 & 100 & 100 & & 47 \\
\hline タンタ & 92 & 100 & 100 & & 0 \\
\hline 白 金 & 92 & 95 & 100 & & 0 \\
\hline 么 & 82 & 99 & 92 & & 0 \\
\hline ズ & 79 & 96 & 91 & & 33 \\
\hline ニッケル & 74 & 100 & 90 & & 0 \\
\hline タングステン & 71 & 81 & 76 & & 43 \\
\hline カドミウム & 56 & 0 & 67 & & 0 \\
\hline セ & 51 & 0 & 99 & & 0 \\
\hline バナジウム & 41 & 70 & 100 & & 0 \\
\hline モリブデン & 0 & 99 & 100 & & 15 \\
\hline
\end{tabular}

Vol. 34, No. 4 ('87-冬) 
第 5 表 主要各国の輸入に占める南アフリカへの依存度 (単位 \%)

\begin{tabular}{|c|c|c|c|c|c|}
\hline 鉱種名一名 & 日本 & 米国 & 英 目 & 酉ド & z \\
\hline 金 & - & - & 66 & 5 & 16 \\
\hline アンチモン & - & 6 & 90 & 15 & 8 \\
\hline ク口 只 鉱 & 42 & 48 & 79 & 66 & 24 \\
\hline フェロクロム & 62 & 79 & 18 & 54 & 37 \\
\hline マンガン 鉱 & 63 & 4 & 46 & 73 & 41 \\
\hline フェロマンガン & - & 45 & 46 & 4 & 1 \\
\hline マンガン(金属) & - & 31 & 74 & 52 & 54 \\
\hline ニッケル & 18 & 4 & - & 17 & 14 \\
\hline バナジウ ム & 86 & 87 & - & 6 & 20 \\
\hline 白 金 族 & 28 & 55 & 58 & 9 & 17 \\
\hline ジルコニウム & 7 & 1 & 7 & 16 & 2 \\
\hline アスベスト & 34 & 4 & 18 & $1 \quad 12$ & 8 \\
\hline 木夕ル石 & 27 & 23 & - & 12 & - \\
\hline
\end{tabular}

西側各国に比べ，ソ連はコバルト，スズ，タングステ ン，モリブデンを除いて自給できる体制にあり，大きな 違いを示している。

てのようなレアメタルの需給状況のもとで, 西側工業 国はレアメタルの多くを南アフリカをはじめとする南部 アフリカに依存している。西側主要国のレアメタル総輸 入量のうち, 南アフリカからの輪入比率は第 5 表の之お りで，極めて高い比率を示すあのが多く，南アフリカの 今後の動向が，西側各国の経済に大きな影響を与えかね ない状況にある。

南アフリカを中心とした資源情勢は以上のとおりであ るが，てれにジンバブエ，ザイール，ザンビアその他の 諸国を加えて，南部アフリカとして資源をとらえると問 題はより大きくなる。また南アフリカは，乙れらの国に 経済的に大きな影響力をあっているとともに，資源輸出 のための輸送路を提供しているととも, 問題を大きくし ている。

このように，南アフリカないし南部アフリカ諸国への 西側各国のレアメタル資源の依存度は極めて高いが，乙 れ之同時に南部アフリカの政情の不安定性と東側の進出 屯，資源の安定供給に下安を抱加せる原因となっている。

1960年代からはじまった南部アフリカ諸国の相次ぐ独 立は, 白人支配からの脱却を目指す白人と黒人之の主権 争いの形で進んできた。ジンバブェ，アンゴラ，モザン ビーク等が社会主義政権のあとで次々と独立するにおよ んで, 問題は唯一の白人国家となった南アフリカの行方 とナミビアの独立をめぐる問題に集約されてきた感があ る。

黒人の社会主義政権のあとで独立した南部アフリカ諸 国の経済運営は, 必ずしも順調之は云えない状況にある。
この原因は，社会主義そのあのの問題に加え，黒人政権 の統治力の不足, 熟練技術者の国外脱出による生産能率 の低下に加えて，世界的な景気後退による鉱産物の需要 減退, 価格の低迷による外貨収入, 財政収入の不足等に あり，国によって事情は多少異なるあのの，いずれも経 済的に深刻な危機的状況に追い込まれている。鉱産物の 価格低迷に対しては，生産資材を自国で供給できる南了 フリカは, ランドの切り下げ効果むあって，むしろ鉱山 各社は高収益をあげているが，他の各国は自国通貨を切 り下げてあ生産資材の輸入価格が上昇し，効果がないば かりか，資材不足に敛まされている状況にある。

また南部アフリカのとのような問題は, 南部アフリカ 地域内の問題にとどまらず, 米・ソ超大国によって二分 される東西両陣営のレアメタル資源をめぐる国際戦略と あ複雑にからんでいる。特にアフリカにおける白人によ る唯一の近代的工業国ともいえる南アフリカの重要性は, 西側の軍事的, 経済的戦略上の問題から, ますますク口 ーズアップされてきている。

一方，ソ連の南部アフリカに対する政策は，さまざま な要素から成り立っていると考えられるが，その主要な あのの一つに西側諸国と同様, ソ連之共産圈諸国のレア メタル資源の確保問題があり，また同時に西側諸国が重 要視する南部アフリカのレアメタル資源の支配ないし供 給の不安定化のねらいがあることは，てれまでのたびた びのソ連要人の発言からもうかがえる。

また西側諸国と南アフリカとの直接的関係についても 複雑な情勢にある。アパルトヘイト問題でゆれ動いてい る南アフリカに対する経済制裁の一つに，金またはクル 一ガーランド金貨と石炭と鉄鋼の輸入禁止問題がとり上 げられている。しかし, クロム, マンガン等のレアメタ ルについては輸入禁止の対象品目としてみえ隠れするも のの，本格的汇議論されたととはない。一方ボタ大統領 は経済制裁措置がとられれば，クロムの輸出を禁止する と述べ，乙れを実行した場合，欧米各国では失業者が增 え，自動車等の産業は大きな打撃を受りるであろうと発 言している。また米国のレーガン大統領は経済制裁に極 めて消極的で，議会の制裁決議に反対して，制裁を実行 した場合にだれが得をするかは明白であると発言し，暗 にソ連の南アフリカへの接近と西側経済の混乱の可能性 に対する影念を表明している。

このように，各国はアパルトヘイトそのあのには反対 するあのの, 南アフリカの急激な変化と, 同国からのレ アメタルの供給障害に不安を抱いているというのが現状 である。

\section{4. レアメタル資源安定供給確保策の現状}

以上のようなレアメタル資源の供給上の問題点に対し 
て，西側工業国が資源の多くを海外に依存していること と, 特に南部アフリカに対する依存度が高いことは, 各 国共通の問題とも云える。

しかしながら，欧米各国は古くから資源大企業を有し， 資源国之の相互依存関係の深さ, 資源生産企業との資本 面, 技術面, 人の面におりるつながりの樑さ等によって, 安定的な供給構造を持続している。加えて欧米各国は, 資源の安定確保と資源供給の途絶と云う事態に対しても 積極的な施策を講している。特に米国，フランス，スイ ス，スウェーデン，ノルウェー，フィンランド，英国で は供給途絶事態に備えて, 大規模な備蓄を実施しており (西ドイッであ検討中), 我が国に比べてはるかに安定的 なレアメタルの供給構造を有している。

一方我が国が資源の安定供給を安全保障問題をす含め た，国全体の問題として検討しはじめたのは，石油危機 後のことであった。

すなわち，二度にわたる石油危機を契機として，資源 小国である我が国の経済基盤の脆弱性が明らかとなって きたためである。それまでの経済運営において，いわば 当然とされていた資源の供給に，途絶という危険性があ ることが現実の問題として認識されるようになり，国際 的な政治経済情勢によって我が国における通常の経済活 動が攪乱されるととへの「備え」が重要な問題として浮 び上ってきたのである。

こうした情勢と認識の変化に応じて, 昭和 51 年 5 月に 決定された「昭和50年代前期経済計画」において，はじ めて経済面での安全保障問題がとりあげられ，資源，工 ネルギー，食糧をめぐる経済的安全に留意すべきととを 指摘している。また昭和 54 年 8 月に決定された「新経済 7 力年計画」でも，我が国にとって不可欠な重要物資に ついて，その安定供給を確保すべく，経済的安全に留意 した対外政策および国内経済運営を行う必要性を強調し ている。

また，昭和 55 年 8 月，当時の鈴木総理が「国の安全を 確保するためには，単に防衛的な側面のみならず, 経済, 外交を含めた広い立場からの努力が必要である。との 考えを表明し，ての考えに基づいて12月には「安全保障 関係閣僚会議」が設置された。閣僚会議では，我が国の 安全保障に係る内外の政治経済情勢および諸施策の状況 について関係省庁からの報告を受けるととあに，

1）国の安全が損われるような事態を未然に防止する ための基本的な考え方

2）国の安全が損われた場合を想定し，平素から整備 しておく対応策等

についての基本的な考え方について協議することとなっ た。

通商産業省では，乙れを受けて産業構造審議会総合部
会の下に「経済安全保障問題特別小委員会」を設置し, 検討を開始するととあに，経済企画庁です，経済審議会 長期展望委員会の下に「経済社会安全小委員会」を設置 し，検討を開始した。

このように, 石油危機以来, 資源の安定供給確保問題 が我が国の安全保障に直接係わる問題として認識される ようになり，各方面で検討が行われるようになったが， この中で特に通常産業省を中心とした検討の経緯とその 概要は次のとおりである。

1）鉱業審議会鉱山部会備蓄問題懇談会

昭和48年の石油危機を契機として，乙の不幸な体験を 省みて，国民生活および産業活動にとって不可欠な原材 料である非鉄金属について，石油之同様の供給停止が生 ずる可能性，生じた場合の混乱の程度，その対策につい て検討を行った. その結果, 石油と同様に非鉄金属資源 について屯国際的な供給体制は極めて流動的になってお り，特に一部の非鉄金属資源については緊急時に備えて 経済上の安全保障の観点から備蓄を行う必要があるとし 昭和 49 年 9 月に報告している。同懇談会ではベースメタ ル, レアメタルを含む 23 鉱種について, 輸入依存度, 偏 在性, 国際企業による寡占性, 供給上の問題点を検討し, 直ちに備蓄を行う必要があり, かつ実施し得る環境が整 っているあのとして, 銅, ニッケル, クロム, タングス テンをあげている。

\section{2）一次産品委員会総論分科会}

通商産業省通商政策局長の諮問機関である一次産品委 員会では，昭和54年度に「資源備蓄」，昭和55年度に「希 少金属資源」というテーマで検討を行っている。

54年度の「資源備蓄」では，資源の安定供給確保政策 における備蓄政策の位置づけおよびその必要性について 検討し, 特に過剩在庫備蓄, 需給緩衝備蓄, 輸入安定化 備蓄等の企業活動から派生する備蓄と国際緩衝在庫のよ うな国際商品協定政策に基づく備蓄とは明確に区分され た, 安全保障を目的とした備蓄の必要性と正当性につい て検討し，55年 8 月に報告している。

また55年度の「希少金属資源」では，22鉱種のレアメ タルについて, 今後の我が国の産業発展の要となるであ ろう。電子産業, 原子力・太陽発電を含むエネルギー産 業, 航空・宇宙産業, 触媒産業等のいわゆる技術先端産 業と, これら産業に必要な素材としての電池，粉末冶金 製品，ファインセラミックス，チタニウム製品，磁性材 料, 特殊鋼等との係り合いについて検討を行っている。 また検討の過程では，これら希少金属の使用の実態，重 要性，今後の見通し，需給，価格等の実態と見通しにつ いて鉱種別に明らかにするととあに，我が国の希少金属 資源の安定供給確保のための対応策についても検討を行 い，56年 9 月に報告している。

Vol. 34, No. 4 ('87-冬) 
3）産業構造審議会総合部会経済安全保障問題特別小委 員会

エネルギー，鉱物資源，食糧等の重要物資について， その経済安全保障の観点からみた重要性, 供給不安定化 の実態, 経済安全保障のための施策のあり方とコスト負 担のあり方等について検討を行い，55年 4 月に「経済安 全保障の確立を目ざして」と題して報告している。

4）経済審議会長期展望委員会経済社会安全小委員会 なお，経済企画庁においても，エネルギー，非エネル ギ一鉱物資源, 食糧 (農産物, 海産物), 木材等の重要 物資をとりあげ，安全保障の観点からみた今後の施策の あり方について検討を行い，57年 4 月に報告している。

これらの報告が共通して強調していることは，鉱物資 源が現代の国民生活及び産業活動にとって不可欠な重要 物資であるてと。国民生活の隅々まで入り込み極めて重 要な役割を果しているととあに，今後の産業のリーダー と目されるハイテク産業にとっては，その死命を制しか ねないほどの重要性を持っていること。乙れに対し経済 大国となった我が国の鉱物資源消費量は世界の $10 \%$ 以上 を占めているにもかかわらず，その国内供給力は極めて そしく，そのほとんどを海外に依存していること。しか し，世界の資源供給構造は極めて不安定であり，短期的 ・突発的および長期的・構造的不安が存在し，ての不安 が我が国の安全保障上極めて重要な問題であり, 脅威で あるとしていることである。

また，乙のような鉱物資源供給上の不安を解消するた めに, 長期的問題点, 短期的問題点に分けて, 概略次の ような対応策が必要であると述べている。

1）資料情報収集, 分析機能の強化

2）脅威発生の防止，長期的・構造的脅威への対応策 (1)資源供給力拡大への貢献 海外における資源開発および資源開発関連経済協 力の促進

(2)国際的需給，価格安定化への努力

(3)未利用資源の有効活用

(4)国内資源の確保

(5)省資源，リサイクリング，代替の促進

(6)技術開発の促進

3）短期的・突発的脅威への対応策
(1)供給先の分散化

(2)国内鉱山の維持, 存続

(3)資源備蓄，特に国家備蓄の推進

このような対応策のうち, 経済安全保障問題小委員会 では，銅，鉛，亜鉛等のベースメタルについては，従来 からの個別の資源確保政策をより一層強化するととすに, 特にレアメタルについては新たな観点から政策を立案し, 総合的な資源の安定供給確保政策を推進することが必要 であり，とりわけレアメタルの国家備蓄制度の創設が急 務であると強調している。

このような経緯を背景に, 昭和58年度から一部民間に あ協力を求める形でレアメタル備蓄制度が創設されたが, 中長期対策については，昭和59年に鉱業審議会鉱山部会 にレアメタル総合対策特別小委員会を設置し，本格的に 検討され，探鉱開発，技術開発，備蓄の三本柱を内容と した報告書が12月提出されている。

通商産業省ではこの報告を受けて, 昭和60年度から次 の施策を実施に移している。

1）レアメタル国内賦存状況調査

2）レアメタル海外探鉱成功払融資

3）レアメタル海外総合開発技術協力調査

4）レアメタル探鉱技術開発

5）レアメタル分離精製技術開発

6）未利用レアメタル有効活用研究技術協力

\section{参考・引用文献}

1）一次産品委員会「資源備蓄」報告，通産省，1980年 3 月

2）一次産品委員会「希少金属資源」報告，通産省， 1981年 3 月

3）産業構造審議会経済安全保障問題特別小委員会報告, 通産省，1982年 4 月

4）経済審議会経済社会安全小委員会報告, 経済企画庁, 1982年 4 月

5）鉱業審議会レアメタル総合対策特別小委員会報告, 通産省，1984年12月

6）希少金属データブック，金属鉱業事業団

7) MINERAL FACTS AND PROBLEMS 1985, U. S. BUREAU OF MINES

8) MINERALS YEARBOOK 1984, U.S. BUREAU OF MINES

9) MINERAL COMMODITY SUMMARIES 1987, U.S. BUREAU OF MINES 